\title{
Can we Punish the Perpetrators of Atrocities?
}

\section{R A Duff ${ }^{1}$}

As [a pirate] has renounced all the benefits of society and government, and has reduced himself afresh to the savage state of nature, by declaring war against all mankind, all mankind must declare war against him. ${ }^{2}$

These are deeds that demand not only condemnation, but damnation in the full religious meaning of the word —-that is, the doer not only puts himself outside the community of men; he also separates himself in a final way from a moral order that transcends the human community. ${ }^{3}$

[Some] may say that even such people are owed unconditional respect, meaning, not that they are deserving of esteem, but that they are owed a kind of respect which is not conditional upon what they have done and which cannot be forfeited. Some will say that even the most terrible evil-doers are owed this respect as human beings and that we owe it to them because we are human beings. ${ }^{4}$

The question that forms the title of this paper, 'Can we punish the perpetrators of atrocities?', invites an obvious and simple answer-an answer which is also true, in a formal sense. Of course we can punish them: if they can be captured and their guilt duly proved, they can be subjected to the institutional process of a criminal trial; they can be formally convicted; the

1 Thanks for helpful criticisms and suggestions are due to participants in the conference on 'The Religious in Responses to Mass Atrocities', but also and especially to Thomas Brudholm and Thomas Cushman.

2 Sir William Blackstone, Commentaries on the Laws of England (1765-69; Oxford University Press); available online at http://www.yale.edu/lawweb/avalon/blackstone/blacksto.htm) IV.5.iii, p. 71.

3 P L Berger, A Rumour of Angels (Penguin, 1970), 87.

4 R Gaita, Good and Evil: An Absolute Conception (Macmillan, 1991), 2. 
court can formally sentence them to imprisonment or even death; pursuant to that sentence, they can be locked in a prison, or killed through the formal process by which death penalties are carried out. From this perspective, there are questions about whether, why, by whom and how those who perpetrate atrocities should be punished; but that they can be punished is not sensibly in question.

However, my concern is not with the institutional form of punishment, but with its moral substance. My question is whether whatever is done to such perpetrators can properly count as punishment—whether it can have the meaning, the moral character, that punishment must have if it is to be justifiable. We can lock such perpetrators up, or kill them: but why should (how could) this count as 'punishment', rather than merely as some kind of incapacitative or preventive detention, or as the disposal of a dangerous enemy or outsider? The formal answer to that question, given above, is that what is done to them counts as punishment if it is done in accordance with the formal penal procedures of a criminal justice system; but, we will see, the substantive answer is much less straightforward. It is less straightforward because, I will argue, if punishment is to be a morally appropriate response to criminal wrongdoing, it must have a communicative, and thus inclusionary, purpose-which is to say that it must address the person punished as a fellow member of a normative community. I sketch this argument in Section 1, before turning in Section 2 to the problems this poses for the punishment of those who perpetrate the kinds of atrocity that make it tempting to call them hostes generis humani or outlaws, ${ }^{5}$ and difficult (impossible?) to recognise them as fellow members of a normative community. In face of this difficult, some would claim that only a religious perspective can make it possible to see such perpetrators as fellows for whom we must strive to retain the kind of respect that punishment should display; I argue in Section 3 that we should resist this claim.

The idea of a 'hostis generis humani' was applied originally (by Cicero) to pirates: Blackstone explains its implications in the passage quoted above. See e.g. C Joyner, 'Arresting Impunity: the Case for Universal Jurisdiction in Bringing War Criminals to Accountability’ (1996) 59 Law \& Contemporary Problems 153. 
(I will not try to define 'atrocities': the kinds of case that make punishment problematic form a sub-class of what are orthodoxly classified as 'crimes against humanity'; ${ }^{6}$ paradigm instances are those systematic exercises in human destruction that display a complete denial of their victims' humanity.)

\section{Punishment, Communication and Inclusion}

On some views of punishment, there is in principle no special problem about the punishment of those who perpetrate atrocities. A consequentialist must ask what goods such punishments can achieve, and whether those goods outweigh the costs that such punishments incur; and it might be far from obvious that the ordinary justifying benefits of consequentialist punishment (deterrence, reform, incapacitation) will be substantially achieved in these cases-especially when the crimes were committed decades ago. ${ }^{7}$ But other benefits may be gained, in terms of the satisfaction of urgent demands, or the possible achievement of some kind of 'closure'; and the question is anyway an empirical or contingent one about the good (and the harm) that such punishments can be expected to bring.

On some versions of retributivism, there is also no in principle problem about punishing such perpetrators. If the purpose of punishment is to inflict the kind and degree of suffering that the wrongdoer deserves, we can ask what kind and degree they deserve: thus Blackstone, in the passage quoted at the start of this paper, goes on to say that 'every community hath a right ... to inflict that punishment upon [the pirate], which every individual would in a state of nature have been otherwise entitled to do'. We might think that no punishment, or none

See the Rome Statute of the International Criminal Court (available at http://www.icc-cpi.int), arts. 5, 7; for commentary, see A Cassese, International Criminal Law (Oxford University Press, 2003), 64-95.

7 See I Tallgren, 'The Sensibility and Sense of International Criminal Law' (2002) 13 European Journal of International Law 561; W Wringe, 'Why Punish War Crimes? Victor's Justice and Expressive Justifications of Punishment' (2006) 25 Law and Philosophy 159. 
that we could allow ourselves to inflict, could be adequate to the atrocious wrongfulness of what they had done, but that would be to say that we could not punish them enough, not that we could not punish them: so Berger suggests that the perpetrator who 'separates himself in a final way from a moral order that transcends the human community ... invokes a retribution that is more than human', since '[n]o human punishment is "enough" in the case of deeds as monstrous as these' ${ }^{8}$ I suggest, however, that the problem of whether we can properly punish those whose crimes are so terrible that they might be seen as hostes generis humani goes deeper than this.

That it goes deeper is suggested by the ease with which such hostes may also be seen as outlaws.

[Terrorists] are hostis humani generis, enemies of all mankind and as such should be viewed as outlaws. Their acts should be treated as offences against the law of nations and every state can and should [bring] them to justice. ${ }^{9}$

Now an 'outlaw' is precisely someone who is outside the law-someone who has excluded himself, or has been excluded, from the protection of the law: but how then can we aim to bring such a person to justice or to punishment, since that is to treat him as being within the law-as being both bound and protected by its norms? Outlaws might be killed, as a matter of public defence, or locked up as a preventive or incapacitative measure, but they cannot qua outlaws be punished: for punishment operates within the law, whilst outlaws are outside it.

This limited point about the idea of an outlaw leads to a larger question about who can be punished, and about the status that a tolerable system of criminal punishment must accord to those whom it punishes.

8 Berger, op. cit. n. 3 above, 87. See H Arendt, Eichmann in Jerusalem: A Report on the Banality of Evil (rev. ed.; Penguin, 1994), 250, on the suggestion that 'Eichmann's deeds defied the possibility of human punishment, that it was pointless to impose the death sentence for crimes of such magnitude' (a suggestion that she herself rejected).

9 Dr. Peter Tomka, Permanent Representative of the Slovak Republic to the United Nations; statement to the United Nations General Assembly $56^{\text {th }}$ Session, Agenda item No. 166: Measures to eliminate international terrorism (New York, October 2001); http://www.un.org/terrorism/statements/slovakiaE.html. 
Punishment, on any plausible theory of its justification, requires a responsible wrongdoer who can be said to deserve punishment for what he has done: whether or not we think that consequential benefits are also necessary to an adequate justification of punishment, we must surely accept the modest claim of the 'negative retributivist', ${ }^{10}$ that if punishment is not deserved, it is not justified; and only a responsible wrongdoer can deserve punishment for what he has done. Now to be responsible is to be answerable: to say that I am responsible for wrongdoing is to say that there is some person or body who has the right or standing to call me to answer (to account) for it. This dimension of responsibility, as an essential condition of criminal punishment, is crucial to the legitimacy of a criminal process of trial, conviction and punishment. A criminal trial is not just an inquiry on an alleged wrongdoer, which aims to determine the truth or otherwise of the proposition that she committed a specified wrong; it is a process through which she is called to answer-to answer to the charge that she committed this crime, and to answer for such wrongful conduct as is proved against her. That is why we cannot legitimately try a person who is so mentally disordered or incompetent that he cannot understand or play any active role in the proceedings (even if he was sane and competent at the time of the alleged offence). We can hold an inquiry to determine whether he committed the crime: but it would be a travesty to put him on trial, since that would be to call to answer someone whom we know is incapable of answering; or to convict him, since a conviction aims to communicate to a wrongdoer the condemnation that he has been proved to deserve. ${ }^{11}$

Now to call someone to account for her alleged wrongdoing is to address her as a fellow member of a normative community. We accuse her of wrongdoing in the light of values that we must claim to be hers as well as ours: not necessarily in the sense that she actually accepts them, but at least in the sense that they are (we must claim) binding on her. We address her as

${ }^{10}$ On negative as distinct from positive retributivism, see D Dolinko, Some Thoughts about Retributivism' (1991) 101 Ethics 537, 539-43.

11 For the English provisions on unfitness to plead (other legal systems have similar provisions), see Criminal Procedure (Insanity) Act 1964. For this conception of a criminal trial, see R A Duff, Trials and Punishments (Cambridge University Press, 1986), ch. 4. 
a fellow member of a normative community that those values define and structure, a member whom those values both bind and protect. In calling her to account, we must also claim the standing to do so: we must claim that her wrongdoing is our business, that we have the right — perhaps also a duty — to intervene in this way; but what makes it our business is that we are fellow members of a relevant normative community. I must answer to my colleagues and my students for my failures as a teacher: they have a right to call me to answer for such failures, and I cannot refuse to answer on the grounds that it is not their business. But if a passing stranger, or a police officer, calls me to answer for such failures, I can properly reply that that is none of their business-I am not responsible to them. ${ }^{12}$

What is the relevant community in the context of crime and criminal trials: to whom are criminal defendants answerable, as members of what community? Different political theories will generate different answers to this question, but for any state that aspires to be a liberal democracy the most plausible answer is that we are responsible, answerable, as citizens to our fellow citizens, as fellow members of a liberal polity. ${ }^{13}$ In our civic lives we are related to each other not by the shared bonds of subjection to the commands of a sovereign (as classical legal positivism portrayed it); nor by anything as intimate and mutually interested as some of the more ambitious forms of communitarianism portray it; nor merely by the limited terms of a social contract between strangers (a contract that cannot be binding if it is truly between strangers): but as participants in a civic enterprise that requires us to recognise each other with a certain mutual concern and respect as citizens, whilst also leaving each other those extensive realms of individual freedom and privacy that are so important to liberals. Within

12 Some might argue that, whilst I am only answerable to a limited set of others for my failures as a teacher, for my moral wrongdoing I am answerable to every other moral agent as such. I do not think that this is true, but need not pursue the issue here: the essential point is that I am answerable to fellow members of a relevant normative community; to say that I am answerable for my moral wrongdoings to all other moral agents would be to say that the relevant normative community is that of moral agents (the Kantian kingdom of ends, perhaps). See further R A Duff, 'Answering for Crime' (2005) 106 Proceedings of the Aristotelian Society 85.

13 On liberal political community, see further R A Duff, Punishment, Communication, and Community (Oxford University Press, 2001), ch. 2; see also R Dagger, Civic Virtues (Oxford University Press, 1997) on republicanism. 
such a liberal polity, the criminal law speaks to us not in the peremptory tones of a sovereign whose commands and prohibitions are given authority by the effective threat of sanctions, but in our own collective voice, and in terms of the values that define and bind us as a polity. The criminal law defines those wrongs that properly count as 'public' wrongs, i.e. wrongs for which I must answer to the polity and its members, and which are the business of my fellow citizens simply in virtue of our shared citizenship. ${ }^{14}$

I have not talked yet of criminal punishment, as something that is imposed on responsible citizens for their wrongdoing; but we can now cast the problem of punishment in a different and sharper light, by asking not just how criminal punishment can be justified in the abstract, but how citizens can justifiably punish each other. For punishment is imposed by courts that claim to speak and act in our name as citizens, under laws that claim to address us as citizens —and 'our' and 'us' include all citizens, offenders and non-offenders alike. The challenge for a liberal penal theory is therefore to show how in punishing offenders we can still claim to be treating them as citizens-as fellow members of the normative political-legal community. ${ }^{15}$

Neither consequentialists nor orthodox retributivists tend to take this challenge seriously, but it faces anyone who espouses the values of liberal or republican political community. I have argued elsewhere that we can meet it only by portraying punishment as an enterprise of moral communication. A criminal conviction communicates to the defendant the judgement that he committed the wrong described in the charge. As a communicative act, it is intended to elicit an appropriate response — of understanding and (ideally) remorseful acceptance: the intention is that the defendant come to understand not merely that he is being treated with hostility, but that and why he is being condemned as a wrongdoer; the hope is that he will

14 To say that crimes must be 'public' wrongs is thus to say not that they must be wrongs that impact on 'the public' as distinct from any direct individual victim (see e.g. Blackstone, op. cit. n. 2 above, IV.1, p. 5), but that they must be wrongs that properly concern 'the public', i.e. the whole polity: see S E Marshall and R A Duff, 'Criminalization and Sharing Wrongs' (1998) 11 Canadian Journal of Law\& Jurisprudence 7.

15 Some deny that that is the challenge, arguing that criminals forfeit their standing as citizens (A H Goldman, 'Toward a New Theory of Punishment' (1982) 1 Law \& Philosophy 57; C W Morris, 'Punishment and Loss of Moral Standing' (1991) 21 Canadian Journal of Philosophy 53): but see Duff, op. cit. n. 13 above, 14-16. 
thereby come, if he has not already come, to make that condemnation his own, by recognising his wrongdoing with remorseful eyes for himself. The punishment that he then receives- the fine, the term of probation, Community Service or imprisonment (although imprisonment can play only a small part in a communicative system of punishment)—gives that condemnation a more forcefully symbolic material form; it too aims to communicate the condemnation that the crime warranted, as part of an attempt to bring the wrongdoer to recognise and confront the wrongfulness of his crime. The offender must be able to understand this dimension of his punishment, and to respond to it appropriately (even if he actually remains unpersuaded and unrepentant). That is why it is wrong, as a travesty of punishment, to punish someone who is so disordered or so impaired that he cannot understand what is done to him as a punishment: we might detain such a person, for his own safety or that of others; but we cannot punish him, since nothing done to him could have the communicative meaning and intent that punishment must have.

Such a conception of punishment as communicative finds its modern roots to Feinberg's influential article on punishment's expressive function; ${ }^{16}$ but by talking of communication, rather than merely of expression, I want to emphasise the way in which punishment should be not just a one-way process of expressing something to or at someone, but a two-way process that aims to engage, and to solicit an appropriate response from, another rational, responsible agent. If all that we do to the offender is to express our anger; or threaten him with sanctions to deter him or others from future crimes; or subject him to restraints to incapacitate him from future crimes; or impose on him some quantum of suffering that is meant to match, in some cosmic balance, the wrong he committed: we cease to address him as a responsible citizen. If, however, punishment can be an attempt to engage in forceful moral communication with the

16 J Feinberg, 'The Expressive Function of Punishment', in Feinberg, Doing and Deserving (Princeton University Press, 1970) 95; for further development and criticism see A J Skillen, 'How to Say Things with Walls. (1980) 55 Philosophy 509; I Primoratz, 'Punishment as Language' (1989) 64 Philosophy 187; M Davis, 'Punishment as Language: Misleading Analogy for Desert Theorists' (1991) 10 Law and Philosophy 311. 
offender, it can be a process that addresses the offender as a responsible fellow citizen—and thus be something that citizens could properly do to each other.

There are very different ways to develop the idea that punishment has a communicative dimension that is central to its meaning and proper purpose: ways that differ, in particular, in how they explain the 'hard treatment' aspect of punishment (the fact that the censure which punishment is to communicate is communicated through measures, such as imprisonment, fines, compulsory community service and the like, that are burdensome quite independently of their meaning); in the answers they give to the question 'Why not communicate censure by purely verbal denunciations, or by purely symbolic punishments that are burdensome only in virtue of their meaning?'. We need not discuss these differences here ${ }^{17}$ all that I need is the argument that punishment must be justified as an appropriate method of communicating to offenders the censure that they deserve for their crimes. As such, it must address them as fellow members of the relevant normative community-of the political community by whose laws they are bound and protected, and to whose other members they must answer as fellow citizens.

This is an essential difference between criminal punishment and other coercive measures whose material substance might be similar to that of punishment-between imprisonment as a punishment and other modes of coerced detention (the preventive detention of those judged to be dangerous, or the quarantine of those diagnosed as being dangerously infectious, or the imprisonment of enemy soldiers); between a fine as a punishment and a tax on or charge for various kinds of activity; between Community Service as a punishment and compulsory work on community projects as a form of conscription. The point is not just that punishment has an essential precondition—criminal guilt—-that these other kinds of coercion lack; it is that the very meaning of such impositions is utterly different when they are imposed as punishments.

17 For two very different versions, see A von Hirsch, Censure and Sanctions (Oxford University Press, 1993) (see also A von Hirsch and A J Ashworth, Proportionate Sentencing: Exploring the Principles (Oxford University Press, 2005)); Duff, op. cit. n. 13 above. 
One crucial point about punishment as communication is that it is an inclusionary, rather than an exclusionary, enterprise. We do not impose punishments on offenders as a positivist sovereign imposes them on her recalcitrant subjects; punishment attempts to engage with the offender as a fellow citizen-someone who has done wrong, but who is not thereby excluded from community. Punishment is quite different from mere expulsion or destruction: it keeps the wrongdoer within the community, and seeks a response from her as a citizen. ${ }^{18}$

It is patently false to claim that criminal punishment, as practiced in many if not all of our existing legal systems, is an inclusionary enterprise. So many of those who suffer punishment had already been excluded from many of the rights and benefits of citizenship—-both from the protection of the values by which the polity claims to define itself, and from real participation in the articulation and development of those values. So much of the rhetoric of criminal law and punishment is exclusionary: offenders are portrayed as enemies against whom the war on crime (or on drugs or on antisocial behaviour) is fought, as a dangerous 'they' against whom the law-abiding 'we' must be protected. So much actual punishment is exclusionary, in its meaning and in its effects: its message to the offender is that she is excluded from community with the law-abiding (this is true especially but not only of imprisonment); and its effects are often to inflict further economic, social and political exclusion on the offenders, whose 'debt to society' has been formally but not in substantive effect discharged. ${ }^{19}$ But to argue that punishment is an inclusionary enterprise is not to deny such glaring facts about our existing

18 I would have liked to be able to argue that a communicative conception of punishment therefore has no room for capital punishment, but (though there are plenty of other powerful arguments against the practice) cannot do so. Someone who has committed a terrible wrong might rationally kill himself as an expression of his belief that his crime cut him off from humanity. By that very act of self-execution he might reconcile himself with those whom he wronged, and capital punishment could thus be meant to communicate to the wrongdoer the message that his crime had this implication, and that execution is the only adequate way of recognising and marking it. I would argue that that is not a message that we should ever communicate, in this way, to another person, but that is a further argument: see Duff, op. cit. n. 13, 152-5.

19 A good indication of the extent to which punishment is in fact exclusionary is the extent to which convicted offenders lose the right to vote, as those serving prison terms do in England during their imprisonment, and as those imprisoned for felonies do for life in some American states. See 'Disenfranchising Felons' (2005) 22 Journal of Applied Philosophy 211-273; J Q Whitman, Harsh Justice: Criminal Punishment and the Widening Divide between America and Europe (Oxford University Press, New York, 2003) provides further useful comparative material on offenders' moral and civic standing. 
systems of criminal justice: it is, rather, to offer a normative account—an ideal—of what criminal punishment ought to be or become if it is to be an acceptable feature of a liberal polity; it is thus also to offer a normative standard against which we can assess and criticise our existing penal practices.

Such a conception of punishment does, I think, make moral sense of criminal punishment as it could be imposed on the majority of offenders: if we are to claim the collective standing to call them to answer and punish them for their wrongs, we must recognise and address them as fellow citizens in the political community. However, it comes under serious strain in some kinds of case, when it is far from clear whether we should, or how we can, seriously maintain that view of the offender. ${ }^{20}$

One such strain arises with those whose criminal careers involve persistent, very serious crimes. It is tempting to argue that, whilst most crimes should not exclude the offender from the community or make it impossible for him to be fully restored to community, someone who persists in committing crimes that flout the most basic bonds of community should in the end be seen to have excluded himself. That idea could underpin some version of the notorious American 'three strikes and you're out' rules: ${ }^{21}$ given a long enough record of serious enough crimes (much longer and more serious than existing 'three strikes' laws require), the offender has put himself 'out' from the political community. Like many liberals, I would to resist such an argument: but to resist it we must appeal to a demanding conception of citizenship as more or less unconditional-a conception such that no criminal wrongdoing, however persistent or serious, can negate the wrongdoer's standing as a citizen. I will not say more about this here, since we turn now to a more extreme version of this problem. ${ }^{22}$

20 One unproblematic qualification to this account should be noted here: that it also allows for the punishment of temporary visitors to the polity. As visitors (as guests of the polity), they are both protected and bound by the local laws; they can be expected, and called, to answer to their hosts for wrongs that they commit as visitors.

${ }^{21}$ See Whitman, op. cit. n. 19, 56-7, and further references provided there.

22 See Duff, op. cit. n. 13 above, 170-4; von Hirsch and Ashworth, op. cit. n. 17 above, 50-61; and further references given in those places to the larger debates about 'dangerous' offenders. 
It is feasible, albeit morally demanding, to see almost all criminal offenders as fellow citizens who must be called to account for their wrongdoing, but to whom we owe respect and concern as fellow participants in the civic enterprise; and so to see punishment, at least in ideal theory, as a communicative enterprise which addresses offenders as responsible citizen. However, when we ask how we can respond to those who commit the most terrible atrocities, the feasibility and desirability of that ideal come into serious question.

\section{Limits to Community?}

One problem raised by such cases, a problem which I cannot discuss in detail here, is that of jurisdiction. ${ }^{23}$ National courts have jurisdiction over crimes committed within the borders of the state-typically crimes committed by and against its citizens: offenders are answerable to that polity and its members, and are called to answer by and before its courts. Sometimes a crime cannot be thus allocated to a single state, since its commission and impact are not thus localised: to deal with such crimes, states must either claim a more extensive jurisdiction to cover them (either unilaterally or by international agreement), or share in the creation of a supra-national court (the development of European criminal law is interesting in this context).

Some trans-national crimes are of a categorically different kind: for they are committed by states, against other states and their members. The most familiar of these are war crimesaggression, as a violation of jus ad bellum, and other war crimes that violate jus in bello. The only morally plausible forum to try such crimes is an international criminal court-either an ad hoc tribunal like that created for the Nuremberg trials in 1945 , or a standing international criminal court of the kind that has now been created. ${ }^{24}$

23 See M Hirst, Jurisdiction and the Ambit of the Criminal Law (Oxford University Press, 2003).

24 See generally Cassese, op. cit. n. 6 above, 327-45; Hirst, op. cit. n. 23 above, ch. 5. 
A deeper puzzle arises when crimes located in particular states are treated as international crimes. This happens in two ways. First, a state's courts might claim 'universal' jurisdiction over certain crimes committed anywhere in the world, whether or not a citizen of that state is involved as either victim or perpetrator: ${ }^{25}$ a theft committed in Chile by a Chilean against another Chilean is no crime in English law, nor triable by English courts; torture committed in Chile by Chilean officials on Chilean citizens, however, is a crime in English law, triable in an English court. ${ }^{26}$ Second, an international criminal court might have jurisdiction, as the ICC has over 'crimes against humanity': although 'crimes against humanity' must be 'part of a widespread or systematic attack directed against any civilian population', that attack can be directed against victims within, as well as outside, the state whose agents commit it. ${ }^{27}$

There are two ways to interpret, and ground, such claims to universal jurisdiction. First, we could say that those who perpetrate 'crimes against humanity' are still ideally answerable to the polity within which they commit their crimes, if those crimes were thus localised, and if there is a polity that can call them to account (which might be problematic): that is why Saddam Hussein is properly tried by an Iraqi court, for his crimes against Iraqi citizens. But sometimes, for a variety of reasons, the local courts and criminal justice system cannot be expected to call the wrongdoers to account-especially when the crimes are committed by or at the instigation of state officials, or the polity's institutions have collapsed. When that is so, other states, or an international court, can properly intervene, and act in the name and on behalf of the citizens whose own local institutions are failing to act: the wrongdoers, that is, must still answer to their own polity, but do so through a foreign or international court.

25 We must distinguish such claims to 'universal' jurisdiction from claims to extra-territorial jurisdiction over crimes committed abroad either by or against the state's citizens, as e.g. in the French Code Penal art. 113.6-7, and the German Strafgesetzbuch ss. 5, 7; see Hirst, op. cit. n. 23, ch. 5.

26 See Criminal Justice Act 1988, s. 134 (giving effect to the UN Convention against Torture and other Cruel, Inhuman or Degrading Treatment or Punishment (1984)); this was the provision involved in $R v$ Bow Street Metropolitan Stipendiary Magistrate ex parte Pinochet Ugarte [2000] 1 AC 147. Other European states have similar provisions.

27 Rome Statute of the International Criminal Court, art. 7.1. This was also a feature of the Charter creating the International Military Tribunal at Nuremberg: see A Altman and C H Wellman, 'A Defense of International Criminal Law' (2004) 115 Ethics 35, 36. 
The alternative reading of such claims to universal jurisdiction takes seriously the idea of 'crimes against humanity': not (primarily) as crimes which victimise or harm 'humanity' as distinct from some more specific group, ${ }^{28}$ but as wrongs which properly concern all human beings simply in virtue of their shared humanity. Thus the Preamble to the Rome Statute talks about 'the most serious crimes of concern to the international community as a whole', and of 'unimaginable atrocities that deeply shock the conscience of humanity'. Many wrongdoings, committed in polities not our own, are not our business: we can be moved by them, regret them, wish that they were not committed; but we lack the standing to call their perpetrators to answer for them. We do not have that standing either as individuals or collectively, through our states or through whatever international institutions we create. Some kinds of wrong, however, should concern us, and are properly our business, simply in virtue of our shared humanity with their victims (and their perpetrators): for such wrongs the perpetrators must answer not just to their local communities, but to humanity.

We will no doubt need to pursue both these lines of thought (which might anyway start to overlap with each other) if we are to find any adequate grounding for such claims to universal jurisdiction, but it is on the second that I want to focus here.

The idea of 'humanity' as a community within and by which perpetrators of atrocities can be called to answer for their crimes to their fellow human beings is clearly problematic, and it might be tempting to dismiss it as nothing more than overblown rhetoric_-or as an arrogant claim to universal jurisdiction by bodies which actually speak only for some set of more local interests. One question is whether it makes any sense to talk of 'humanity' as a community at all-whether we can really say that all human beings are united by some set of shared values or concerns, in something recognisable as a shared life, in virtue of which we can be expected

28 See the Preamble to the Rome Statute on 'grave crimes' which 'threaten the peace, security and well-being of the world'; also Arendt, op. cit. n. 8, 269; see also L May, Crimes against Humanity: A Normative Account (Cambridge University Press, 2005) on the 'international harm principle'. For criticism, see Altman and Wellman, op. cit. n. 27, 40-42; see also n. 14 above, on the related idea of crimes as 'public' wrongs. 
to recognise any other human being as a fellow. ${ }^{29}$ Even if we can talk of such a community in some aspirational sense, a second question is how and by whom it could be given appropriate political or legal shape: can we see the UN, or the ICC, as speaking and acting for 'humanity' —or only as structures through which nation states can try to pursue their own interests and to ward off a Hobbesian state of inter-national nature? A third question, if the first two can be answered satisfactorily, will then concern the proper scope of an international criminal law: for what crimes should which perpetrators have to answer to 'humanity'? Whom could such a court properly call to account, for what?

I cannot answer these questions in detail here, but should at least indicate the direction in which answers may lie. On the first question, the idea of a common humanity is not so very strange: some might cash it out in Kantian terms of the kingdom of ends; others will look for less rationalistic, religious or humanistic ways of understanding it. ${ }^{30}$ Integral to such an idea is a conception of what we owe to each other, by way of respect and concern, in virtue simply of our shared humanity; such respect arguably includes a readiness to answer to other human beings, in terms of the values that I recognise as binding and protecting us all, for whatever conduct is properly their business. That is, perhaps, enough for us to be able to talk of the community of humanity, once we recognise that communities can be partial and relatively thin: that they need not involve sharing richly all-embracing forms of life. ${ }^{31}$ However, there are obvious differences between the idea of answering individually to other people as fellow human beings, and that of answering before an international court to humanity-differences analogous to those between answering individually to fellow citizens for my civic failures,

29 Compare the Preamble to the Rome Statute, on the signatories' 'conscious[ness] that all peoples are united by common bonds, their cultures pieced together in a shared heritage'.

30 See R Gaita, Good and Evil: An Absolute Conception (Macmillan, 1991) and A Common Humanity (Routledge, 2002) for a rich and complex humanistic perspective on this; I discuss Gaita further in section 3 below.

31 This point is crucial to the possibility of a liberal political community (see Duff, op. cit. n. 13 above, 42-56). It is also clearly relevant to 'cosmopolitanism' - the question of whether we should cultivate a single 'human community' (see P Kleingeld and E Brown, 'Cosmopolitanism', in E Zalta (ed.), The Stanford Encyclopedia of Philosophy (Fall 2002 Edition) http://plato.stanford.edu); but we cannot pursue that topic here. 
and answering to the polity before a criminal court for my crimes: these lead us to the other two questions.

As to the second question, the obstacles in the way of creating institutions that can truly claim to speak for humanity are clearly formidable, given the extreme differences in power and resources, and the deep differences in fundamental values, between the states that would be most directly involved in that process, and the scope that the creation of such an institution offers for ideological conflict and imperialism; we need not say more about those difficulties here. It is however worth suggesting — at least as a thought that might have force in our more optimistic moods - that the attempt to create and operate an International Criminal Court can itself help to create, as well as to express, the kind of community of humanity in whose name it is to act.

As to the third question, the ICC has jurisdiction over genocide, crimes against humanity, war crimes, and the crime of aggression. ${ }^{32}$ It is worth noting that these crimes, in virtue either of their formal definition in the Statute or of the limitations of individual agency, require both a collective victim, and a collective agency which, even if it does not include state officials, acts at the instigation or with the connivance of the state. ${ }^{33}$ However, we cannot pursue the question of just how, and how broadly, 'international' crimes should be defined here; what is more important for present purposes is the question of who can be called to answer for them, since it is this question that become problematic in the case of atrocities.

One point that should have emerged from s. 1 is that to call someone to answer to us is to see her as a fellow member of some normative community by whose values we are all bound, protected, and liable to be judged. That is to say, if we are to call someone to answer to us, we must be able to see her as someone who falls under a normatively laden description under

32 See the Rome Statute of the International Criminal Court, Article 5; articles 6-8 further define the first three types of crime.

33 See generally Cassese, op. cit. n. 6 above, ch. 4; also Altman and Wellman, op. cit. n. 27 above (although they favour a more extensive definition of 'crimes against humanity' than is currently orthodox, they still insist on involvement by the state or by state officials, as committing, instigating or permitting the crimes. 
which we also fall: as, for instance, as a colleague who is answerable to us, as her colleagues, for her performance of her job; or as citizen who is answerable to us, as her fellow citizens, for her conduct in the civic enterprise in which we are all engaged; or, we can now add, as a human being who is answerable to us, as her fellow human beings, for wrongs that concern all human beings. Now faced by the perpetrator of terrible atrocities, and especially if we try to see him through the eyes of his victims, we can of course recognise that in a formal sense he is a human being, as we are: but can we recognise, and address, him as a fellow human being in the substantive sense that is needed if we are to call him to account or punish him $?^{34}$

Just why is this problematic? Our understanding of the crimes that such a person commits is structured by our recognition that he is a human being and a moral agent: the horror that we feel at such crimes is in part a horror that a human being could do that to his fellows; and our description of his crimes as atrocities is precisely a description of things done, not by natural causes or by a human being who is so mentally disordered that he cannot be seen as a moral agent at all, but by a human moral agent.

However, to call someone to account, whether informally outside the law or formally at a criminal trial, goes further than that (this was part of the point of s. 1): it is to address him, to try to communicate with him, as someone who shares with us in a form of life, and to whom we therefore owe the kind of respect and concern that flow from the values which structure that form of life. That shared form of life, that normative community of which we recognise our common membership, need not be rich in its shared content. Given the wide diversity of human communities, human lives and human goods; given the ways in which we are relative strangers to most other human beings: what unites us as human beings must be something fairly minimal, perhaps fairly abstract, in its content. But if we are to talk of crimes against

34 Hannah Arendt (op. cit. n. 8 above, 251) quotes Martin Buber as saying that he had 'only in a formal sense a common humanity with those who took part' in the atrocities committed by the Nazis; to which she replies that 'the law presupposes precisely that we have a common humanity with those whom we accuse and judge and condemn'. She also argues that '[n]o communication was possible' with Eichmann, given his 'inability ... to think from the standpoint of somebody else' (49). My question is: can we even try to communicate? 
humanity whose perpetrators must answer to humanity, we must suppose such a substantive commonality; we must be able to address the wrongdoer, not (merely) with hatred, horror, disgust or contempt as someone who is 'beyond the pale', but as a responsible moral agent with whom we endeavour to engage in this communicative process of calling to account and judgement. For communication is essentially a two-way enterprise: it requires us to recognise the other as a participant in (not merely the object of) the process of explanation, persuasion and judgement in which we are engaged; we must be able to say to the other something along the lines of 'Let us discuss this issue, and try to work towards an appropriate judgement'; it requires that we respect the other as a participant in this process, so as someone to whom we must be willing to listen as well as talk; it requires that we are ready, indeed that we aspire, to reach an agreement which would allow us to speak with one voice about the matter under discussion.

If the account of criminal punishment sketched in the previous section is plausible, then similar points must apply to the punishment of those who perpetrate even the most atrocious crimes against humanity; to punish them should be to attempt still to communicate with them as fellow members of some normative community; in punishing them we must endeavour to recognise and respect their moral standing, and to address them not as outlaws (who cannot be punished), but as fellows - fellows who have committed grievous wrongs, but with whom we still recognise our fellowship.

But can we, or should we, aspire to such a substantial recognition of fellowship when we face those who have committed the most terrible atrocities? We can try to determine whether they committed the atrocities. If we determine that they did so, we can kill them, or lock them up to protect others, or exile them from human community. But can we call them to account at a trial, or punish them as a way of trying to communicate with them as fellows? Should we not recognise, would we not come to recognise if we really grasped the full character of the 
wrongs that had been committed, that by their crimes they put themselves beyond the bounds of human community; that their utter denial of their victims' humanity, and their systematic attacks on humanity, have destroyed the possibility of human community with them? These questions gain added force when we think of perpetrators who themselves continue to deny any such community with those whom they wronged or those who now call them to account: what sense does it make to try to engage in the kind of mutually communicative enterprise that, on the account sketched above, criminal trials and punishments should be, with someone whose words and demeanour make clear his contemptuous rejection of the court's authority, and his determined refusal to engage in any such process, or to recognise the values to which it appeals? The moral possibility of trials and punishments does not, of course, depend upon their actual success in bringing wrongdoers to engage in the communicative enterprise, or to answer for, to repent, or to make amends for their crimes: we must address the wrongdoer as someone who could respond appropriately, else there is no sense in seeking a response from him; but the value and importance of the attempt to engage him in a penal dialogue does not depend on its actual or likely success. ${ }^{35}$ However, faced by a perpetrator whose past deeds and present demeanour at his trial make clear his utter contempt for the values in whose light we seek to call him to answer, we must surely wonder whether we should, or really can, treat him as a fellow member of any normative community.

(Who are 'we' in this context? The 'we' includes not just the victims of the atrocities, or those with particular ties to them: it is the 'we' of humanity in whose name the courts act, and to whom the perpetrator is to answer; to ask what this 'we' can or should do is to ask what we could or could not do if we had the appropriate kind of concern for our fellow human beings, including the victims of these crimes, and fully grasped the nature of the crimes. However, the victims' perspective is clearly crucial: we must ask whether we could see the perpetrator

35 See further Duff, op. cit. n. 13 above, 121-5. The central idea here, which comes under real pressure in the context of atrocities, is that we should never see or treat anyone as being beyond the reach of remorse- not even if we have very good empirical grounds for believing that they will not be persuaded into remorse. 
and his deeds from the victim's perspective, and still recognise him as a fellow human being with whom we must try to engage in a communicative enterprise of calling to account. ${ }^{36}$ )

It might seem that I have invented an unreal problem here: for surely someone convicted of such atrocious, humanity-denying crimes can still be punished appropriately, by exclusion or exile from the human community that he himself so completely denied? Arendt suggested that the Israeli court should have said to Eichmann 'we find that no one, that is, no member of the human race, can be expected to want to share the earth with you. This is the reason, and the only reason, you must hang' ${ }^{37}$ This is also one reading of Berger's comment, quoted at the start of this paper, that such deeds 'demand not only condemnation, but damnation in the full religious meaning of the word'; 'the doer not only puts himself outside the community of men; he also separates himself in a final way from a moral order that transcends the human community'. ${ }^{38}$ There is, however, a crucial difference between saying about a person that his deeds 'demand' expulsion, and saying to him that he must be expelled as a punishment. The latter is what conviction and punishment properly require (if the argument of s. 1 was right); but what it requires is therefore that we seek the wrongdoer's agreement to the judgement that his conviction and punishment express; and here we face a serious problem.

I suggested earlier that capital punishment could, in principle, be a communicative mode of punishment $;{ }^{39}$ it could indeed in principle be a punishment that an offender accepts, or that he imposes on himself, in recognition of what he sees as the implications of his crime, and a way in which he can reconcile himself in death with those whom he wronged. To address the offender in this way is still to address him as a fellow member of the moral community, albeit

36 A further, related question which I cannot pursue here concerns the responsibilities of surviving victims of atrocities: could we expect them to engage in the process of calling the perpetrator to account, i.e. to address him as a fellow? On victims' responsibilities in the criminal process, see generally S E Marshall, 'Victims of Crime: Their Station and its Duties', in M Matravers (ed.), Managing Modernity: Politics and the Culture of Control (Routledge, 2004) 104.

37 Arendt, op. cit. n. 8, 279.

38 See at $n .3$ above. Expulsion or exile need not involve execution; it could take the form of imprisonment for the remainder of the person's natural life, although the character of that imprisonment would be radically different from that of imprisonment as a punishment.

39

See n. 18 above; I should emphasise again that I am not arguing in favour of capital punishment. 
as one who, we think, must leave the community (I think the apparent paradox here is only an apparent one). But if our judgement is that he 'separates himself in a final way from a moral order that transcends the human community', that appears to cut off the possibility of trying to communicate with him in this way-in which case we can kill him or lock him up, but we cannot punish him.

We can see this point by attending to much less dramatically terrible examples. Someone who has lost patience with an acquaintance's persistent misconduct might say dismissively 'I've got nothing to say to him'. In saying that she is turning away from the wrongdoer, and renouncing (or marking what she takes to be his renunciation of) whatever relationship they had-as acquaintances, as neighbours, as colleagues: whilst that relationship survives, she should be willing to talk to him—including talking about his misconduct; but with its demise, that commitment to communication also dies. ${ }^{40}$ In less serious cases one does not deny all community with the wrongdoer-he is still at least a fellow human being; but the example illustrates the point that communication requires a recognition of community. If criminal trials and punishments are communicative enterprises, they too require a recognition of normative community with the wrongdoer: but is this possible with those who commit the kinds of terrible atrocity that Berger is talking about?

\section{Religious and Secular Conceptions of Community}

Perhaps we should simply accept that there are limits to community: whilst we must strive to recognise our fellowship with most other human beings, including serious offenders, we need not, or perhaps in moral honesty should not, think that we can preserve community with those

40 Matters are slightly more complex if what she says is 'I've got nothing to say to you', thus communicating to the wrongdoer her judgement that (further) communication is impossible or undesirable; that is analogous to the case in which a wrongdoer's punishment is exile. 
who commit the most terrible atrocities—in which case, I have agued, we must recognise that we cannot punish them, or hold them responsible for their deeds. We can, of course, subject them to simulacra of trial and punishment: we can bring them to court, follow the rituals of a trial, present the evidence against them; the court can pronounce a verdict and sentence; the material substance of that sentence (death or imprisonment) can be carried out. Such rituals might serve various useful purposes: to reaffirm our collective commitment to the values that were flouted, and our solidarity with the victims; to bring some satisfaction to the surviving victims and those who loved them. But they would not be trials and punishments in the strict or proper sense: they would not constitute an enterprise of calling a wrongdoer to answer for his wrongs. To which it might be said-why should we expect to be able to engage in such an enterprise with such people? Calling someone to answer, holding someone responsible, is a communicative endeavour which presupposes normative community; normative community requires at least a modicum of mutuality; but such wrongdoers reject any such mutuality with their victims and with those who would now hold them to account.

Furthermore, punishment as a communicative enterprise normally presupposes a prospect of reconciliation with the community within which one is called to account: the wrongdoer is called to recognise and repent his wrongdoing, and by undergoing punishment to make moral amends for it-amends which give forceful material form to the apology that he owes those he has wronged; by making such amends, he can achieve some kind of reconciliation with his fellows. ${ }^{41}$ But could we, should we, even hope for such reconciliation with the perpetrators of such terrible atrocities? Could we (and could they) recognise the full reality of what they had done, and still think that through punishment and penitence they could be reconciled with their victims and with the wider community? Should we not instead recognise that they have irrevocably excluded themselves from the possibility of human community?

41 On punishment, apology, making amends and reconciliation, see Duff, op. cit. n. 13 above, ch. 3; C Bennett, 'Taking the Sincerity Out of Saying Sorry: Restorative Justice as Ritual' (2006) 23 Journal of Applied Philosophy 127. 
But yet-is it senseless, or morally crass or blinkered, to harbour the hope that we could still try to recognise and treat even such perpetrators as our fellow human beings; to hope that we could still try to communicate with them through an appropriate criminal process of trial and punishment? I am certainly not arguing that we should do this: before we begin to talk in such impersonal or universalist terms of what 'we' or 'one' should do, or of what should be done, rather than in first person singular terms of what I can or cannot find it within myself to do, ${ }^{42}$ we must ask what kinds of response are morally intelligible, given what preconditions or assumptions; and it is this question of intelligibility that concerns me here. Can we find a morally intelligible conception of community that would make it morally possible to see the perpetrators of even the most terrible atrocities as our fellows, with whom we can still try to engage in the kind of process of moral communication that, I have argued, criminal trials and punishments should constitute?

Perhaps, however, this is the wrong question. For there are people, even some surviving victims of atrocities, who precisely do manage to maintain such a responsive recognition of the perpetrator-who can bring themselves, for instance, to face the perpetrators at a trial and to speak not merely about them, but to them as moral agents who must be brought to face what they have done. We can admire such people; we can wonder both at their courage and at their moral capacity still to see the other's humanity; we surely should not say that they are wrong or misguided. So our question then must not be whether it is possible still to recognise such perpetrators as fellow members of a normative community, but how it is possible: what conception of community, and of the person, could ground such attitudes and responses to those who have perpetrated atrocities?

It would be very hard, or impossible, to ground them in familiar secular conceptions of normative community. Think, for instance, of the various kinds of contractualist account both

42 On 'I' and 'we' in ethics, see L Wittgenstein, 'A Lecture on Ethics' (1965) 74 Philosophical Review 3; see also Wittgenstein's remarks as quoted in F Waissmann, 'Notes on Talks with Wittgenstein' (1965) 74 Philosophical Review 12, at 16. 
of morality and of civil and political society-accounts according to which our dealings with each other should be determined by the terms of a contract that we are to imagine making with each other. ${ }^{43}$ Insofar as such conceptions have a place for ideas of community at all, they portray us as sharing our moral and political communities with our fellow contractors-with those whom we can see as parties to the contract: it is to them that we owe whatever duties of respect and concern the contract specifies. Now a contract can of course survive breaches of its terms (and rational contractors will agree penalty clauses to deal with such breaches), but there will be limits to this: the maintenance of the contractual relationship is conditional on at least a minimal level of continuing reciprocity; some breaches of the contract, and especially systematic and unremedied breaches of its most basic terms, will be terminal, in that they will effectively render the contract null and void. Anything I owe to you as a contractual matter is in that way conditional or contingent on your conduct towards me: if you utterly disregard the contract, it ceases to bind me. But if anything can void a social or moral contract, surely the systematic perpetration of the kinds of atrocity we are concerned with here must do so: to put the point sharply, how can such crimes not negate the possibility of a continuing contractual relationship between perpetrator and victim.

Now it is true that many of our moral relationships are not best understood on the model of a contract: it would be a strange friendship in which the friends' mutual concern could be expressed in contractual terms. ${ }^{44}$ It is also true, however, that many of those relationships do involve a kind of pre-contractual (if not proto-contractual) notion of reciprocity, and that they are conditional or contingent on that reciprocity persisting. Whilst I do not see my friendships as contractual matters, and even if they transcend the defective kinds of friendship based on

43 Contractualism takes many different forms. For paradigm examples of different brands of contractualist theory, see e.g. J Rawls, A Theory of Justice (Harvard University Press, 1971); D Gauthier, Morals by Agreement (Oxford University Press, 1986); T Scanlon, What We Owe to Each Other (Harvard University Press, 1998).

44 Jeremy Waldron's insightful discussion of the relationship between rights and such moral relationships as marriage and friendship is relevant here: 'When Justice Replaces Affection: The Need for Rights' (1988) 11 Harvard Journal of Law and Public Policy 625. 
pleasure or utility that Aristotle identified, ${ }^{45}$ they are not unconditional; amongst the factors that can (quite reasonably) destroy a friendship are persistent, serious breaches of the norms or demands of friendship. When we turn from such intimate relationships as friendships to our relations with our fellow citizens, or with strangers with whom all we have in common is our humanity, we are even more likely to see those relationships as ones in which reciprocity is crucial: whilst we should initially do unto others as we would want them to do unto us, if they persistently and utterly fail to respond appropriately, we cease to see any requirement to continue such treatment. In some intimate relationships, we might aspire to an unconditional regard for the other: that is one ideal of family relationships—of the love that parents could have for their children, and children for their parents; it could also be one ideal of marriagealthough it was at least more common in religious (or Christian) conceptions of the marriage bond as ordained by God, than in secular conceptions of marriage. ${ }^{46}$ But that is not how we typically understand our relationships with those who are not thus intimately connected to us: if strangers persistent in flouting the most basic bonds of reciprocal community, how can we not respond to them with a version of 'I have nothing more to say to you'; if they persistently turn their backs on the minimal values that bind us, how can we not turn our backs on them?

If we think in these terms, we might also think that only a religious perspective can allow or help us to recognise continuing community even with the perpetrators of the most terrible atrocities-in which case, if the arguments of the earlier parts of this paper are right, only a religious perspective can allow us to punish such perpetrators. That is not of course to suggest that all we need add in is some or other religious perspective: we are after all familiar enough with religious beliefs according to which serious enough wrongdoing can exile the wrongdoer permanently from God's love, and thus no doubt also from other human beings. But it might

45 Aristotle, Nicomachean Ethics, VIII-IX.

46 A radical example of such an unconditional conception of the bonds of marriage is provided by Stephen Blackpool in Charles Dickens' Hard Times: his wife leaves him, and returns only when she needs his help; each time she returns, he takes her in, helps her back to health—and then sees her leave again; for she is still his wife. 
seem that two kinds of religious idea would help. First, and most importantly, the idea that we all have an absolute, unconditional, non-contingent status as God's creatures: a status that reflects God's love for his creatures, and that demands of all of us an equally unconditional, non-contingent regard for other human beings as God's creatures. Second, perhaps, the idea that certain kinds of punishment are a matter for God rather than for us. Perhaps it is true of a perpetrator that he "not only puts himself outside the community of men; he also separates himself in a final way from a moral order that transcends the human community'; but such a final and irreversible condemnatory judgement is not for us to make-it is for God. ${ }^{47}$

Rai Gaita points us towards one version of this suggestion when he says, in talking about how we could respond to the kinds of evil perpetrated by the Nazis,

[i]n the face of such evil some people believe that they must assert, and others that they must deny, that even people who have done such deeds are sacred. Few people will say that in full seriousness because only someone who is religious can do it. ${ }^{48}$

It is true that an idea of the sacred requires what is in some sense a religious metaphysic: the sacred is that which is sanctified by its participation in or infusion by something transcendent, something lying beyond human life and, perhaps, human understanding. (It is also true, of course, that this notion of the 'religious' is far from precise, once we recognise that it reaches beyond specifically theistic world views.) Gaita goes on to say, however,

But there are people who are not religious who want to say what they hope will be a secular equivalent of it and they will hunt for one of the inadequate expressions available to us to do it. ${ }^{49}$

47 Compare M Perry, 'Does Liberal Democracy Need Religious Faith? The Dignity and Inviolability of Every Human Being' (forthcoming; I am grateful to Michael Perry for allowing me to see an advance copy of this paper): Perry argues that liberal democracy's commitment to human rights requires a commitment 'to the proposition that each and every human being has inherent dignity and is inviolable'-a commitment which can find an adequate grounding only in a religious perspective. Though my concern here is not with human rights as such, what follows is meant to be the start of an answer to Perry's argument.

49 Loc. cit.. The rest of his book is an extended exploration of the sense and significance of these 'inadequate expressions': see especially ch. 3 on 'Mortal Men and Rational Beings'; also Gaita's A Common Humanity (Routledge, 2000). 
Amongst these 'inadequate expressions' are that

even such people are owed unconditional respect, meaning not that they are deserving of esteem, but that they are owed a kind of respect which is not conditional upon what they have done and which cannot be forfeited. Some will say that even the most terrible evil-doers are owed this respect as human beings and that we owe it to them because we are human beings. That amounts to saying that they remain our fellow human beings whatever they do (p. 2).

The respect that we owe them has to do in large part with the ways in which we must not treat them or see them-it is expressed in the thought that "no human being may be killed in the spirit of ridding the world of vermin' (p. 3): but it follows from this too that anything we do to them must be consistent with that recognition of them as fellow human beings, as trial and punishment are. ${ }^{50}$

It is of course (as Gaita emphasises) one thing to say such words, one thing to talk in the comfortable context of a philosophical seminar about the unconditional respect that we owe to every other human being in virtue of our shared humanity; and quite another thing to live one's life in that spirit, and to respond to 'the most terrible evil-doers' in that spirit: all I can try to do here is to suggest, following Gaita, that it is a possible perspective, a possible (albeit enormously challenging) spirit, from within which the trial and punishment of perpetrators of even the most terrible evils can become possible. Much more also needs to be said about the kind of moral metaphysic that has room for such notions of absolute value and unconditional respect, since they can certainly find no room in the kinds of empiricist or naturalist views of the world that inform the most familiar contemporary moral theories-including, for obvious examples, the various versions of Utilitarianism and contractualism. We might look to Iris Murdoch's attempt to retrieve a Platonic notion of the Good as a secular focus of attention: ${ }^{.5}$

\footnotetext{
See especially Gaita, 'Evil Beyond Vice', in A Common Humanity (n. 49 above), 29.

I Murdoch, The Sovereignty of Good (Routledge, 1970); another useful source is R F Holland, 'Is Goodness a Mystery?', in his Against Empiricism (Blackwell, 1980).
} 
although her idea of transcendence involves in the end a detachment from human concerns that is deeply problematic, the 'just and loving gaze' that she takes to be crucial to the moral life could be seen as a kind of gaze upon, a kind of attitude towards, other people that is both informed by and a route towards a recognition of their unconditional or absolute value. The point I want to emphasise, however, is that whilst the attempt to make sense of a perspective or attitude of this kind must indeed take us beyond empiricism and naturalism; whilst it must take us into what is in one sense a transcendent metaphysics, which appeals to a conception of humanity that cannot be captured from within a physicalist or scientistic world view: it need not take us beyond the secular and the human, into a specifically religious or theistic metaphysics that posits a god on whom human beings depend for their existence and value. ${ }^{52}$

That recognition of the other is partly a matter of recognised fellowship (I see her as a fellow human being who shares my-our-human fate, and who for that very reason has an unconditional claim on my concern); and partly a matter of recognised separateness (I see her as an independent being who marks a limit to my will, and who thus has an unconditional claim on my respect). To those of a materialist bent, this will seem metaphysically baffling: how could our material world contain such beings as these $?^{53}$ Such a metaphysical concern, however, can hardly give us reason to look to a religious world view for a secure moral foundation: gods are metaphysically at least as puzzling as are human beings when conceived as loci of value. What underpins claims that any such moral perspective requires a religious grounding is rather, I suspect, concerns about point or motivation, in particular the thought that a Christian God provides a point to, a motivation for, taking human beings seriously as loci of value, and sources of reasons for action, which would otherwise be lacking.

52 One can of course use 'religious' in a broader sense, to refer to any moral perspective that reaches beyond or deeper than the limits of a pleasure- or desire-based Utilitarianism, or of a strictly contractualist morality grounded in claims about what rationally self-interested beings would agree; but I take it that the interesting question in this context is whether a recognition of the absolute or unconditional moral status of all human beings requires a specifically theistic grounding.

53 Compare J L Mackie's notorious 'argument from queerness' against the reality of moral values, in Ethics: Inventing Right and Wrong (Penguin, 1977), 38-42. 
That thought is clearly illustrated in Perry's argument, and in particular in his claim that 'there are no categorical imperatives, only hypothetical imperatives'. ${ }^{54}$ If I am to be given good and motivationally efficacious reason to behave in a certain way towards others, I must be shown the point of doing so. That 'point' will lie in some further good that such conduct, such a way of living, can be expected to secure; the appeal is thus 'If (or since) you value that good, you ought to conduct yourself thus'. That appeal will be rationally authoritative, and motivationally efficacious, only if it is an appeal to something that I already care aboutfor an obvious instance, to my own ultimate well-being. Given a suitable theology, we can say (Perry argues) that for each of us our well-being depends upon our recognising others as having an inviolable moral status and treating them accordingly. But without such a theology, he argues, we cannot thus connect an unconditional concern and respect for others to our own well-being, and thus cannot give it the rational grounding that it needs if it is to motivate us.

This is not the place for a discussion of whether we can make sense of imperatives that are genuinely categorical, or of 'external' reasons for action that do not depend on what the person for whom they are to be reasons already wants or values. ${ }^{55}$ All I would say is that the kind of recognition of the other that Gaita explicates, and to which I am appealing here, does indeed involve a recognition (a recognition that is in itself motivationally forceful) of certain moral demands as having a categorical and unconditional authority, independent of my own existing desires or goals; but that such recognition of moral demands is both intelligible and essential to a plausible morality. ${ }^{56}$ What is more relevant for present purposes is the form that this recognition can take in the case of those who have perpetrated atrocities.

54 Perry, op. cit. n. 47 above, xxx. See also his comments about finding inviolability and dignity in a world bereft of meaning — of the kind of meaning that a Christian God might provide (xxx-x).

55 On categorical imperatives, see J McDowell, ‘Are Moral Requirements Hypothetical Imperatives?' (1978) 52 Proceedings of the Aristotelian Society, supp. vol., 13 (responding to P R Foot, 'Morality as a System of Hypothetical Imperatives' (1972) 81 Philosophical Review 305); on external reasons, see J Dancy, Practical Reality (Oxford University Press, 2000), contra B A O Williams, 'Internal and External Reasons' in Williams, Moral Luck (Cambridge University Press, 1982) 101.

56 Gaita's works, and the works by Murdoch and Holland cited in n. 51 above, show how this dogmatic claim can be fleshed out and rendered plausible; see also R A Duff, 'Desire, Duty and Moral Absolutes' (1980) 55 Philosophy 223. 
As I have argued already, one form that it can take is precisely the attempt to call such people to answer, to hold them responsible, for their crimes: to do that is already to address, to recognise, them as fellow members of a normative community by whose values we are all both bound and protected; it would make no sense to try to call a genuinely amoral monster to account. Such a calling to account might be informed by anger, indignation, hatred, even contempt and disgust - by a whole range of what Strawson described as 'reactive attitudes': ${ }^{57}$ but it addresses the wrongdoer as someone who could hear (if he would only listen) what we say, and could respond appropriately to it (even if we are empirically sure that he will not do so); as someone of whom it makes sense to hope (however empirically vain we might know such hope to be) that he will come to face the terrible truth of what he has done. The same is true of punshment, understood as an attempt at moral communication: the punishment must be administered in the hope (however vain) that the wrongdoer will come to see it as what he should suffer for what he has done, and accept it as an appropriate (secular) penance; which means that we must see the wrongdoer as someone who could be brought to such a repentant understanding of his crimes and his punishment. This is not to say that we must expect that he will in fact respond to his punishment in this way: but an implication of this conception of human beings is that we must never see anyone, whatever they have done, as being beyond repentance and thus beyond redemption. ${ }^{58}$

There are further and difficult questions to tackle about what could count as 'redemption' in this context, and about just what it would be for such a wrongdoer to come to an adequate, repentant understanding of what he had done-about what form such repentance could take, and what kind of action or life could express it. Although such questions bear directly on the question of just how such perpetrators could be punished (if punishment is meant to induce a

57 P F Strawson, 'Freedom and Resentment' (1962) 48 Proceedings of the British Academy 1 (reprinted in G Watson (ed.), Free Will ( $2^{\text {nd }}$ ed., Oxford University Press, 2003), 72).

58 Compare E Garrard, 'Forgiveness and the Holocaust' (2002) 5 Ethical Theory and Moral Practice 147 (but I am not arguing here that forgiveness of such perpetrators is either possible or desirable); and see Duff, op. cit. n. 11 above, 264-6. 
repentant understanding), we cannot pursue them here. All I have argued is that if we are to punish the perpetrators of atrocities (as distinct from merely killing them or locking them up), we must be able to see, to address, and to respond to them in this way.

I have certainly not argued that this is what we ought to do-let alone that it is how those most directly affected by such atrocities ought to see and treat those who perpetrated them. I have tried to show, first, that this is what is required if we are to punish them; and second, that it is possible (which is not to say that it is anything less than extraordinarily difficult) to see and to respond to them thus as fellow human beings whom we must try to call to account, from within a firmly secular view of the world. 